UDC 027.7 (574):[616-036.22:004.9]

Yap J. M.

Library, Nazarbayev University (Nur-Sultan, Kazakhstan), e-mail: joseph.yap@nu.edu.kz, ORCID 0000-0002-7852-1047

\title{
LIBRARY PROMOTION AND USER ENGAGEMENT IN PANDEMIC TIMES: THE CASE OF KAZAKHSTAN
}

Objectives. In these trying times due to the global effect of pandemic, what social media accounts do academic libraries in Kazakhstan maintain and how can they improve their social media engagement to continuously connect with their stakeholders? This report provides an overview of the current status of social media engagement of selected academic libraries in Kazakhstan during the COVID-19 crises. This paper will give us a picture about the kinds of online postings shared by these libraries particularly with the use of Facebook. Methods. The top two universities ranked by Independent Quality Assurance Agency (IQAA) were considered in this report to be compared with the only autonomous organization of education in Kazakhstan. The library social media accounts of these three organizations were investigated to review the number of followers, frequency of posting, and its overall social media engagement. Data collected is publicly available to all potential users, followers, or subscribers. Using the post engagement rate (PER) formula introduced by Socialbakers (2013) and adapted by Peñaflor (2018) and Magno (2016), this report identifies and analyzes the average PER Facebook pages maintained by academic libraries. The engagement metrics looked into the number of interactions and the widest reach possible in every post. All three academic libraries investigated maintain a Facebook page. The other account was just created last February 2020. To compare Facebook data during the pandemic times, public information available from June - August 2020 was measured. Results. The social media platforms operated by the academic libraries in Kazakhstan are Facebook, Twitter, Instagram, VK, and YouTube. One of the earliest academic library Facebook accounts established in Kazakhstan started in 2010 with less than 3,000 accumulated followers after ten years. This shows a very slow rise in the number of followers considering an academic population of more than 5, 000 people in 2020. Data revealed that Eurasian National University Library's Facebook account had a higher PER of 0.83 even if it only debut in 2020 compared to the Facebook page of Nazarbayev University which garnered 0.22 PER. KAZNU Library's Facebook page had the highest PER of 1.02. Conclusions. Facebook is the most popular social media platform across the globe but it is not the case in Kazakhstan. Library marketing and promotion in Kazakhstan needs to be addressed as public relations is not the primary focus. The utilization of social media as a tool for user engagement is not fully developed. One way to look at it is to consider library staffing and identify their marketing background. The pandemic situation must be the turning point of academic libraries to enhance their reach with their stakeholders. It was a test to know the readiness of the library in terms of online communication and interaction.

Keywords: social media; user engagement; academic libraries; pandemic; COVID-19; Facebook; Kazakhstan

\section{Introduction}

The use of social media as a tool for library promotion narrows the communication gap among the library's target users. Keeping up to date regarding library services is one of the perceived benefits of utilizing social media accounts (Jones \& Harvey, 2019). While Facebook is the most popular social network worldwide (Statista, 2020b), it only remains to be the third most popular in Kazakhstan as reported by Kazpravda (2019) with only 413,026 active users. VK or Vkontakte is the most popular social media in the country with almost two million active users followed by Instagram with over a million subscribers. One of the earliest academic library Facebook accounts established in Kazakhstan started in 2010 with less than 3,000 accumulated followers after ten years. In these trying times, how can academic libraries in Kazakhstan improve their social media engagement? This report provides an overview of the current status of social media engagement of select academic libraries in Kazakhstan during the pandemic times.

Nazarbayev University (NU) is the flagship university in Kazakhstan. It was established in 2010 by former President Nursultan Nazarbayev and became autonomous in 2011 (Nazarbayev 
University, 2019). This young university is proving to be one of the best universities throughout the country by offering internationally accredited programs and being one of the leading researchbased institutions across Kazakhstan. Recently, the Foundation Program received full accreditation of its English for Academic Purposes program for a period of four years from the British Association of Lecturers in English for Academic Purposes. NU education is at par with European standards as the Graduate School of Public Policy also received full accreditation from the European Association for Public Administration Accreditation.

In comparison with other state universities, the Independent Quality Assurance Agency (IQAA) in Education released the national rankings of the best universities in Kazakhstan in 2020. The top two universities named in the list are Al-Farabi Kazakh National University (KAZNU) in Almaty with a very high rating of 98.71 and followed by L. Gumilyov Eurasian National University (ENU) in Nur-Sultan with a rating of 82.75 (e.gov, 2020). NU Library will benchmark itself with the top two academic libraries in the IQAA 2020 list.

This report delves into the social media engagement of three university libraries during the pandemic times. As libraries continue to provide access to a wealth of information and knowledge resources which are vital and crucial to a researcher's life, it also needs to stay active in reaching out to the needs of its users regardless of the situation. A communication arm is a central element to stay connected with its clients. It must be considered that one of the criteria when evaluating what constitutes a best university is availability of the best facilities and resources, and one of them is the library.

\section{Review of Related Literature}

Facebook claims to be the most popular social network site reaching almost 3 billion users a month with India, United States and Indonesia having the biggest audience size (Statista, 2020a). In 2017, Kazakhstan had a 5.47\% engagement rate for Facebook link posts among other kinds of posts like video, photo, or status posts (Statista, 2019).

The fast turnaround of information in social media has both advantages and disadvantages. People can easily get the latest news through Facebook or Twitter but one has to be careful with the multitude of misinformation tagged as infodemic (Lima, Lopes, \& Brito, 2020). Social media is widely used by many organizations to distribute timely updates and the library is one of them as they keep an abundance of authoritative information. While the library has the responsibility to teach users how to be selective and evaluative when it comes to filtering information online, social media also exists to build and reconnect a community divided by physical distance to protect themselves from the spread of virus.

\section{Social Media as a Marketing Tool in Libraries}

The value that products and services have is strengthened when people apply marketing strategies to offer and exchange these goods to those who want and need them (Ihejerika, Goulding, Calvert, 2018; Kotler \& Keller, 2012).

Furthermore, marketing strategies solidify the relationship of the library and its customers by putting emphasis on the concerns and needs of users (Jones \& Harvey, 2019). It must also be underscored that social media as the trending marketing tool should not be the library's sole ingredient in reaching out to the users and social media should form only part of a diverse marketing strategy.

\section{Social Media Engagement in Academic Libraries}

Lam, Au, and Chiu (2019) reported in their research study that Facebook is the most used marketing tool by libraries. The most frequent content being shared is about library events and each status bears photographs with links. Same authors recommended to regularly review the page performance of the library's social media accounts. Libraries should also consider other kinds of digital technology approaches to attract younger audience. Similarly, Peñaflor (2018) added that 
there is a great need for libraries to arrive at a conscious effort "on increasing user interaction by providing a variety of and engaging content" (p. 64). An interesting post of an image must start a conversation (Shafawi \& Hasan, 2018). The quality of the post will make it more inviting for users to engage.

\section{Methods}

The top two universities, namely Al-Farabi Kazakh National University (KAZNU) in Almaty and L. Gumilyov Eurasian National University (ENU) in Nur-Sultan, ranked by Independent Quality Assurance Agency (IQAA) were considered in this report to be compared with the only autonomous organization of education in Kazakhstan - the Nazarbayev University (NU). Quantitative content analysis was applied in this study. The library social media accounts of these three organizations were investigated to review the number of followers, frequency of posting, and its overall social media engagement. Data collected is publicly available to all potential users, followers, or subscribers. Using the post engagement rate (PER) formula introduced by Socialbakers (2013) and adapted by Peñaflor (2018) and Magno (2016), this report identified and analyzed the average PER Facebook pages maintained by academic libraries.

The PER formula is:

Total Likes + Comments + Shares

Average post engagement rate = -------------------------------------- x 100

Total Posts / Total Page Likes

The study will only focus on one social media platform which is Facebook, the most popular of all. The engagement metrics looked into the number of interactions and the widest reach possible in every post. Data were collected manually and summaries were presented below. All three academic libraries investigated maintain a Facebook page. It is apparent that one of the accounts particularly of the ENU Library was created only in February 2020. Because the lockdown period started in mid-March 2020, it is better to look into the data at least after two months to give time for the Facebook account of grow. To compare Facebook data during the pandemic times, public information available online from June - August 2020 was analyzed, observed and measured.

\section{Results and Discussion}

Table 1. Social media accounts maintained by select academic libraries in Kazakhstan

\begin{tabular}{|l|c|c|c|c|c|}
\hline \multicolumn{1}{|c|}{ Library } & Facebook & Twitter & Instagram & YouTube & VK \\
\hline ENU & $\mathrm{x}$ & $\mathrm{x}$ & $\mathrm{x}$ & $\mathrm{x}$ & $\mathrm{x}$ \\
\hline KAZNU & $\mathrm{x}$ & & $\mathrm{x}$ & & $\mathrm{x}$ \\
\hline NU & $\mathrm{x}$ & $\mathrm{x}$ & $\mathrm{x}$ & $\mathrm{x}$ & \\
\hline
\end{tabular}

Table 1 shows ENU Library maintains five social media platforms for communication and interaction with its library users. ENU Library has the major social networks that suggest strong user engagement. According to world rankings, Facebook has more than 2 billion active users, 
YouTube with 2 billion users, Instagram with over a billion users, and Twitter with 326 million users (Statista, 2020b). VK or VKontakte is regarded as the Russian counterpart of Facebook. It has 65.2 million active users (Statista, 2020c). Following ENU Library is NU Library which maintains Facebook, Twitter, Instagram and YouTube while KAZNU Library only maintains Facebook, Instagram and VK. This data is based on publicly available information showed in the library website/portal of these three university libraries. Data was extracted last on 10 September 2020.

Table 2. Facebook and Instagram followers of select academic libraries in Kazakhstan

\begin{tabular}{|l|c|c|c|}
\hline \multicolumn{1}{|c|}{ Library } & Facebook followers & Facebook likes & Instagram followers \\
\hline ENU & 993 & 982 & 5,654 \\
\hline KAZNU & 85 & 68 & 699 \\
\hline NU & 2,470 & 2,354 & 580 \\
\hline
\end{tabular}

ENU Library's Facebook page was created only in February 5, 2020 yet it already has almost 1,000 followers with 982 likes (Table 2). One reason of having more likes might be the huge number of student population with almost 16,000. NU Library's Facebook page was created in October 21, 2010 while KAZNU's Facebook page started in May 17, 2017. KAZNU also has an older Facebook page created in January 22, 2016 with 136 followers. The last status was posted in February 2017. KAZNU's Library page only received 68 likes while NU Library page had the highest with 2,354 likes. KAZNU's student population is almost 20,000 while NU is only 6,000. With these numbers, the social marketing team of KAZNU has to improve in getting more likes since the page started in 2016. The same with NU Library page that started in 2010 but only established less than 3,000 followers after a decade.

As mentioned previously ENU Library also has a Twitter with only two followers, a YouTube account with 22 subscribers and VK with 344 members. NU Library has also Twitter with 30 followers and a YouTube account with 78 subscribers.

Table 3 Facebook data comparison among ENU, KAZNU, and NU Libraries

\begin{tabular}{|l|c|c|c|c|c|}
\hline \multicolumn{1}{|c|}{ Library } & $\begin{array}{c}\text { Number of } \\
\text { posts }\end{array}$ & $\begin{array}{c}\text { Number of } \\
\text { Likes and } \\
\text { reactions }\end{array}$ & $\begin{array}{c}\text { Number of } \\
\text { Comments }\end{array}$ & $\begin{array}{c}\text { Number of } \\
\text { Shares }\end{array}$ & PER \\
\hline ENU & 23 & 138 & 1 & 48 & 0.83 \\
\hline KAZNU & 26 & 15 & 0 & 3 & 1.02 \\
\hline NU & 43 & 194 & 6 & 24 & 0.22 \\
\hline
\end{tabular}




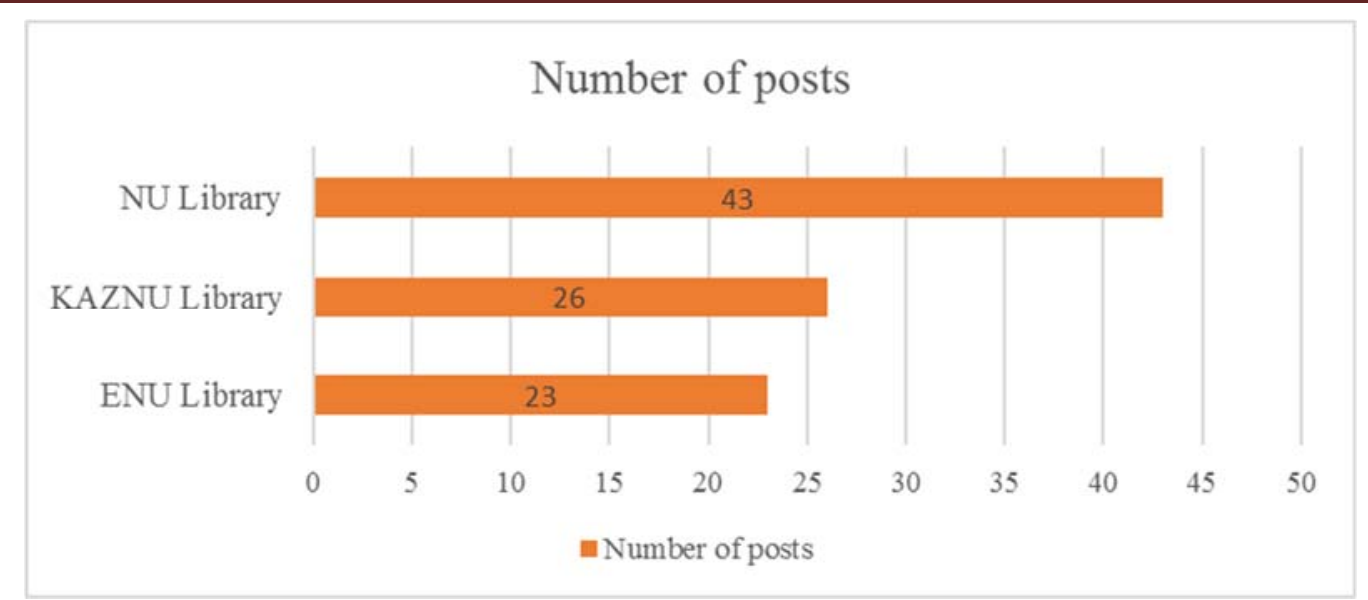

Figure 1. Number of posts for a period of three months (pandemic times)

For a period of three months from June - August 2020 during the novel coronavirus (COVID-19) pandemic, data were manually collected from the Facebook pages of ENU, KAZNU and NU Libraries. Table 3 shows Facebook data comparison among three academic libraries. The following data were extracted: number of posts, number of likes and reactions, number of comments per post and number of shares. Data revealed that KAZNU Library Facebook page had the highest PER of 1.02 among three libraries. It is followed by ENU Library with 0.83 and finally NU Library with 0.22 . NU Library's Facebook page had the most number of posts (Fig.1). Having a small amount of Facebook followers of only 68, KAZNU Library was able to maintain a steady online interaction with its followers. It has to improve more on getting comments from its users as it did not get anything for a period of three months. The followers became passive during the pandemic times. ENU Library Facebook page followers are active in sharing content while NU Library Facebook followers are more active in sending reaction emojis. Moreover, NU Library Facebook page generated more posts from June - August 2020 as compared to the other two university library Facebook pages.

It is also noticeable that there are posts with no interactions at all. KAZNU Library Facebook page had $64 \%$ with no interactions while NU Library Facebook page had $9.3 \%$ with no interactions.

All three library Facebook pages share content mostly including photographs of an upcoming or finished event, promotion of a library collection, announcement of a webinar, historical moments in the country related to Kazakh literature, achievements of the university or the library and its personnel, or changes in library policies during quarantine period, and how to stay connected, safe and healthy. Some links shared contain YouTube links, slideshows and curated videos. Less post is also given on how to interact with the library during the pandemic situation. Libraries could have taken the opportunity to post on certain ways how to keep safe and healthy during quarantine or who to contact in the library for research related requests. ENU Library pays tribute to Kazakh poets and laureates including new publications by ENU scientists by sharing them in their Facebook pages. KAZNU Library posts about their book collection and how to search using their catalog. They also post protocols related to COVID-19. NU Library Facebook page shares their content in three languages especially if it is about library events. Known that there are 92 days from June 1 - August 31, NU Library had a 46.74\% daily posting rate, KAZNU Library had a $28.26 \%$ daily posting rate, and ENU Library had a $25 \%$ daily posting rate. 


\section{Conclusions and Recommendations}

The use of social media particularly of Facebook is not new in Kazakhstani academic libraries. While Facebook is the most popular social media platform across the globe, it is not the case in Kazakhstan as VK is the most prolific. The existence of a library Facebook page can be traced back a decade ago when Nazarbayev University Library launched it in October 2010. Another popular social media platform used in Kazakh academic libraries is Instagram which was also being utilized by Eurasian National University Library, Al Farabi Kazakh National University Library and Nazarbayev University Library.

During the three-month lockdown period from June-August 2020 because of pandemic, KAZNU Library generated the highest PER with 1.02. This was a result of having a low number of total Facebook likes. Having the highest PER amongst the three academic libraries does not mean the posts are well received since they have the highest percentage of posts with no interactions. The huge student population of KAZNU Library will help them increase their Facebook followings if they follow a good social media marketing plan.

All three libraries should improve the frequency of their posts by making it more interactive. Times have changed and the younger generation has seen the latest technological trends. As Lam, Au and Chiu (2019) suggested, libraries should now be well adapted to technology and find approaches that could attract younger audience. Library marketing and promotion in Kazakhstan needs to be addressed as public relations is not the primary focus. The utilization of social media as a tool for user engagement is not fully developed. One way to look at it is to consider library staffing and identify their marketing background.

Maintaining more than one social media platform is also overwhelming. There must be more library personnel inclined in marketing who can focus on planning and strategy, market research, product creation and design, and other support services needed. They are the experts who can provide professional service (Yap, 2020). Without people, the marketing plan will suffer no matter how great the idea is. The pandemic situation must be the turning point of academic libraries to enhance their reach with their stakeholders. It was a test to know the readiness of the library in terms of online communication and interaction.

\section{REFERENCES}

e.gov. (2020). National ranking of the best universities of Kazakhstan. Retrieved from https://egov.kz/cms/en/articles/2Fbestuniinkz30 (in English)

Ihejerika, K., Goulding, A., \& Calvert, P. (2018). How social is your social media? Managing social media marketing in academic libraries. Retrieved from http://library.ifla.org/2142/1/128-kingsley-en.pdf (in English)

Jones, M. J., \& Harvey, M. (2019). Library 2.0: The effectiveness of social media as a marketing tool for libraries in educational institutions. Journal of Librarianship and Information Science, 51(1) 3-19. doi: https://doi.org/10.1177/0961000616668959 (in English)

Kazpravda. (2019, August 26). Most popular social media in Kazakhstan named. Retrieved from https://kazpravda.kz/en/news/society/most-popular-social-media-in-kazakhstan-named English)

Lam, E. T. H., Au, C. H., \& Chiu, D. K. W. (2019). Analyzing the use of Facebook among university libraries in Hong Kong. The Journal of Academic Librarianship, 45(3), 175-183. doi: https://doi.org/10.1016/j.acalib.2019.02.007 (in English) 
Lima, D. L., Lopes, M. A. A. \& Brito, A. M. (2020). Social media: friend or foe in the COVID-19 pandemic? Clinics, 75. doi: http://dx.doi.org/10.6061/clinics/2020/e1953 (in English)

Magno, L. (2016). Using Facebook metrics to measure student engagement in Moodle. International Journal on Open and Distance e-Learning, 2(2), 39-48. Retrieved from http://ijodel.com/wpcontent/uploads/2017/02/004_Magno.pdf (in English)

Nazarbayev University. (2019). History. Retrieved from https://nu.edu.kz/about-nazarbayevuniversity/history (in English)

Peñaflor, J. (2018). "Beyond "likes": An assessment of user engagement in Facebook among Philippine academic libraries". Library Management, 39(1/2), 59-65. doi: https://doi.org/10.1108/LM-12-

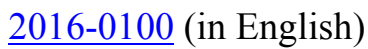

Shafawi, S., \& Hassan, B. (2018). User engagement with social media, implication on the library usage: A case of selected public and academic libraries in Malaysia. Library Philosophy and Practice, 5, 131. Retrieved from https://digitalcommons.unl.edu/libphilprac/1820/ (in English)

Socialbakers. (2013). Engagement rate: A metric you can count on. Retrieved from https://www.socialbakers.com/blog/1427-engagement-rate-a-metric-you-can-count-on (in English)

Statista. (2019). Average Facebook post engagement rates in Kazakhstan in 2017, by post type. Retrieved from https://www.statista.com/statistics/827385/kazakhstan-engagement-rates-of-facebook-posts/ (in English)

Statista. (2020a). Leading countries based on Facebook audience size as of July 2020. Retrieved from https:/www.statista.com/statistics/268136/top-15-countries-based-on-number-of-facebook-users/ (in English)

Statista. (2020b). Most popular social networks worldwide as of July 2020, ranked by number of active users. Retrieved from https://www.statista.com/statistics/272014/global-social-networks-rankedby-number-of-users/

Statista. (2020c). Number of monthly active mobile users of VKontakte (VK) from March 2016 to December 2019. Retrieved from https://www.statista.com/statistics/425429/vkontakte-mobile-mau/ (in English)

Yap, J. M. (2020, June 1). Marketing library programs, services, and initiatives in time of infodemic. [Video file]. Retrieved from https://www.youtube.com/watch?v $=$ osl tkU-JyM (in English)

Яп Дж. М.

Бібліотека, Назарбаєв університет (Нур-Султан, Казахстан), e-mail: joseph.yap@nu.edu.kz, ORCID 0000-0002-7852-1047

\section{ПОПУЛЯРИЗАЦІЯ БІБЛІОТЕК ТА ЗАЛУЧЕННЯ КОРИСТУВАЧІВ У ПАНДЕМІЧНІ ЧАСИ: ПРИКЛАД КАЗАХСТАНУ}

Введення. Облікові записи у яких соціальних мережах підтримують академічні бібліотеки в Казахстані у ці важкі часи через глобальну пандемію та як вони можуть покращити свою залученість до соціальних мереж, щоб постійно спілкуватися зі своїми користувачами? Ця доповідь містить огляд поточного стану використання соціальних мереж академічними бібліотеками Казахстану під час кризи COVID-19 та дає нам уявлення про види публікацій в Інтернеті, які публікують ці бібліотеки, особливо у Facebook. Методика. У доповіді розглянуто два найкращих університети в рейтингу Незалежної агенції забезпечення якості освіти (IQAA), щоб порівняти їх з єдиною автономною організацією освіти в Казахстані. Облікові записи цих трьох організацій у соціальних мережах досліджувались 3 метою перевірки кількості підписників, частоти публікацій та їх загальної залученості до соціальних мереж. Зібрані дані $є$ загальнодоступними для всіх потенційних користувачів, послідовників або підписників. Використовуючи формулу розрахунку коефіцієнту 
залученості публікації (PER), представлену компанією Socialbakers (2013) та адаптовану Peñaflor (2018) i Magno (2016), у цій доповіді визначено та проаналізовано середні показники коефіцієнту залученості публікацій на сторінках у Facebook, які ведуть академічні бібліотеки. Метрики залучення враховуватимуть кількість взаємодій та найбільше охоплення у кожному дописі. Усі три досліджені академічні бібліотеки ведуть обліковий запис Facebook. Один обліковий запис був створений лише у лютому 2020 року. Тому для порівняння даних Facebook за часів пандемії проаналізувано загальнодоступну інформацію, викладену 3 червня по серпень 2020 року. Результати. Платформами соціальних мереж, якими користуються академічні бібліотеки Казахстану, є Facebook, Twitter, Instagram, VK та YouTube. Один з найдавніших бібліотечних облікових записів у Facebook, створений у Казахстані, розпочав свою діяльність у 2010 році і через десять років накопичив менше ніж 3000 підписників. Це свідчить про дуже повільне зростання кількості послідовників, враховуючи академічну чисельність населення понад 5000 осіб у 2020 році. Дані показали, що обліковий запис Євразійського національного університету у Facebook мав вищий показник коефіцієнту залученості публікацій, 0,83, незважаючи на те, що його було започатковано лише в 2020 році порівняно 3 сторінкою Назарбаєв університету у Facebook, яка набрала 0,22\%. Сторінка у Facebook бібліотеки КазНУ мала найвищий показник залученості публікацій - 1,02. Висновки. Facebook - найпопулярніша платформа соціальних мереж у всьому світі, але в Казахстані це не так. Бібліотечний маркетинг та просування бібліотечних послуг в Казахстані потребують вирішення, оскільки зв'язки з громадськістю не $є$ головним напрямком роботи. Соціальні мережі як інструмент залучення користувачів ще не повністю використовуються. Один із методів вирішення цього питання - це розглянути штат бібліотеки та визначити його маркетинговий досвід. Ситуація з пандемією має стати поворотним пунктом для академічних бібліотек, спонукати їх до розширення охоплення більшої кількості користувачів. Це був тест на готовність бібліотек 3 точки зору онлайн спілкування та взаємодії.

Ключові слова: соціальні мережі; залучення користувачів; академічні бібліотеки; пандемія; COVID19; Facebook; Казахстан 